\title{
Where are they now? Tracking the longitudinal evolution of environmental businesses from the 1990s
}

\author{
Dr Diane Holt, \\ Queen's University Management School, \\ Queen's University Belfast, \\ Email: d.holt@qub.ac.uk
}

\section{Keywords}

Small business, ecopreneurs, entrepreneurs, mergers, social enterprise

\begin{abstract}
In 1991 Bennett published one of the first major publications on the concept of ecopreneurship, business opportunities resulting from the emerging environmental agenda of the late 1980s and early 1990s. Since then a body of literature has developed that explores the idea of the intersection of entrepreneurship with environmentally and socially responsible behaviour. Many of the business cases presented by Bennett represent early adopters of green products, services, and emerging eco-markets. Given the current emphasis on the transformation of business practices towards a more sustainable paradigm it is timely to review these 94 early ecopreneurial examples and consider their status two decades on from the original publication. This paper explores the definitions of environmental and social enterprise, and considers the longitudinal survival of these companies and the emerging trends in consolidation and failure of the sampled companies.
\end{abstract}

\section{Acknowledgements}

Financial support for this research was provided by The Nuffield Foundation (SGS/37471). The views expressed are those of the author.

\section{Accepted for publication in Business Strategy and the Environment (2011)}




\section{Introduction}

The publication of the Brundtland report in 1987 marked the emergence of the term 'sustainable development' into public consciousness (WCED, 1987), alongside an implicit agreement with the technocentric environmental management paradigm (after O'Riordan, 1976) that economic growth and environmental protection were not mutually exclusive goals. This period of the early 1990's saw an increasing focus on the business opportunities offered by emerging alternative lifestyle choices, new environmental legislation, and the recognition of the competitive advantages for businesses from the 'green' agenda. Traditional businesses were encouraged to transform their operations to reflect more concern for environmental, and latterly more social, issues (Dyllick and Hockerts, 2002; Elkington, 1997; Hillary, 2000; Holt, 2000; Revell and Blackburn, 2004; Saunders, 1993). There were also calls for new business creation models, especially the creation of 'green' small and micro organisations (Bennett 1991; Berle, 1991), and the opportunity offered by innovation within these SMEs for more sustainable business models (Cohen, 2006; Larson, 2000). Randjelovic et al. (2003:241) suggests that environmentally-oriented entrepreneurship has a key role in sustainable development, and that such firms are typically smaller, fast moving start-ups.

Alternative lifestyle choices such as self-sufficiency, organic food production, slow food movements, fair-trade, artist communes, post consumer waste recycling, and natural/handmade crafts all offered opportunities for small businesses to generate an income and also meet goals associated with socially and/or environmentally responsible business practices. Bennett (1991) presented arguably one of the first 'best practice' publications on what he described as 'Ecopreneuring', a range of case examples of business developments (mostly small) reflecting the sustainability agenda of the time. Recently researchers have refocused on the creation of enterprises with an environmental (and more latterly social) mission (Dickson et al., 2007; Ivanko, 2008; Schaper, 2005). However there has been little reexamination or longitudinal analysis of these early ecopreneurial examples.

It is estimated $99.9 \%$ of all enterprises in the UK and USA are small and medium-sized enterprises (SMEs) (BERR, 2008; SBA, 2007). When considering the 9.2 million enterprises with up to nine employees in both economies, the opportunity for enterprises to deliver more sustainable goods and services is vast. This 'micro' group in the UK comprises of $96 \%$ of the total number of enterprises, $33 \%$ of employment and $23 \%$ of turnover (BERR, 2008). Media coverage of environmental and sustainability issues indicates that sustainability discourse within the public sphere has reached unprecedented levels over the intervening two decades since Brundtland and continues to increase worldwide (Barkemeyer et al., 2009). Thus it is perhaps timely to reflect on the 1991 examples that Bennett presented. These examples provide a fruitful opportunity to consider the longitudinal evolution of ecopreneurs, as early examples of the types of 'green' small businesses that eco-initiatives, and arguably the social enterprise agenda, are now promoting. The majority of previously published studies on ecopreneurs either describe case examples (Bennett, 1991; Ivanko, 2008), present typologies (de Bruin and Lewis, 2005; Linnanen, 2005; Walley and Taylor, 2002), or explain issues associated with start-up (Freimann et al., 2005). Little consideration has been given to the longitudinal evolution of ecopreneurs that includes representation from a range of sectors, different business lifecycle stages and considers those that no longer exist or have static/minimal levels of growth. This papers aims to present a holistic definition of ecopreneurial businesses and to revisits Bennett's original ecopreneurial businesses almost two decades later to consider their longitudinal evolution and current business status. 


\section{Methodology}

Typically identifying and collecting data on a sample of SMEs is hampered by lack of publicly available data and access to the companies, especially when they have failed. In this paper the Bennett publication is used as a historical document that represents businesses considered to be 'best practice' examples in 1991. Content scanning of the Bennett (1991) book identified any mention of individual companies. Information presented on these cases was distilled to a summary table of business focus, ownership, location, and information, if available, on initial financing and business status in 1991. Even when some of this data was not mentioned within the Bennett text the companies were included with blank data cells. However, only examples that provided sufficient information for identification were included (typically name, location and function). Scanning identified 94 companies with sufficient information for further investigation. In the second stage, online search engines and LexisNexis were used to identify if the company is still operating, any name changes, current business status, the services currently offered, and any other pertinent information on success/failure and business development since 1991.

There are limitations to the data collection approach adopted in this paper. Whilst most organisations have some form of online record this is perhaps not true of the smallest. Names of companies also change and may lead to confusion in the search process. Therefore only cases with a number of data points (name, location, function) were used. In the third stage the Manta financial website was used as the primary source of financial data and company information as they use Dun and Bradstreet, a source used in many research studies that has a special emphasis on SMEs. However, since the online data may contain errors, wherever possible data was verified by a second online source (such as a second financial website).

The Bennett sample should also be considered a convenience sample and perhaps reflects a geographical and sectoral bias reflecting the nature of access by the team who collected the original data. The original publication was developed using a consultancy based research team who collected data through telephone interviews, newspaper articles, experience from their own client networks and previous projects. The author was based in New England and there are a number of examples from this region within the original sample.

Using archival information in the form of newswires to identify a sample and explore business developments is a useful technique to gain historical data. However the primary limitations in this study relate to the missing gaps in data such as start up dates, difficulties in establishing reasons for failure or disappearance by a small enterprise, and incomplete information especially concerning internal dynamics such as management practices and financing.

\section{Ecopreneurship Concepts and Classification}

\section{Defining Ecopreneurs}

Entrepreneurship and sustainability are considered to be the emergent paradigms of the late $20^{\text {th }}$ Century (Anderson and Anderson, 1998) and the intersection of these disciplines offers many opportunities for the exploration of new forms of business creation and operation. Entrepreneurship is considered easy to identify but hard to define: "enterprising individuals who find unsolved problems, unmet needs or wants and resolving these to transform the existing status quo into a future opportunity and commercial reality" (Schaper, 2005, p.5). This commercial reality creates value for the entrepreneur 
that is commonly related to in monetary or economic terms rather than more intangible personal values yet "the attitudes which inform environmentalism..... create areas of value which can be exploited entrepreneurially" (Anderson and Anderson,1998 p. 135). Exploration of the relationship between the entrepreneurship discipline and the (natural) environment is embryonic (Cohen et al., 2008), though there is an emerging theoretical base described by a variety of terms such as ecopreneurship (Bennett, 1991; Schaper, 2002), eco-entrepreneurship (Randjelovic et al. 2003), environmental entrepreneurship (de Bruin and Lewis, 2005; Schaltegger, 2005), sustainable entrepreneurship (Masurel, 2007), enviropreneurship (Menon and Menon, 1997), green entrepreneurship (Berle, 1991) and green-green businesses (Isaak, 1997). These terms all describe some aspect of 'entrepreneurship through an environmental lens' (Schaltegger, 2005).

Ecoprenuring is defined by Isaak (1997, p. 80) as 'system-transforming, socially committed environmental businesses characterised by breakthrough innovation' with the focus placed on ecological-purpose business ventures. Ivanko (2008, p. 23) makes this link to ecological ventures clear stating that green entrepreneurs:

'emblazon the greening of Earth, restoring degraded lands, cleaning the air, building healthy and safe home, devising clean, renewable energy sources, offering prevention orientated alternative to treatment focused healthcare and helping to preserve or restore the ecological and cultural winders of the planet by changing the way we experience travel'.

Lober (1998) considers environmental entrepreneurship to be the creation of new products, services or organisations to meet environmental market opportunities. Whilst, Hendrickson and Tuttle (1997, p.363) consider this as 'entrepreneurial activity that benefits the environment'. The majority of recent publications on ecopreneurship are compiled in a reader by Schaper (2005) who defines the distinguishing characteristics of ecopreneurship as: entrepreneurial in some shape or form; commercial activities that have a net positive impact on the environment and move towards a sustainable future; and an intentionality where the ecopreneurs personal belief system sees environmental protection and a more sustainable future as important goals in their own right. This incorporation of 'sustainability' also suggests an implicit commitment to a social dimension. The inclusion of intentionality is also important as it precludes 'accidental ecopreneurs' where the environmental outcomes are accidental by products of other business activities (Schaper, 2005). Ivanko (2008) also describes ecopreneurs as having a social mission in addition to his more explicit 'Earth Mission', suggesting that some enterprises considered social entrepreneurship might fall into their classification.

The US Small Business Administration notes the growing importance social enterprise (SBA, 2007). Nicholls $(2006$, p.2) believes that social entrepreneurship has emerged as a global phenomenon as a result of social and environmental demand and supply side developments. He describes social entrepreneurs as pragmatic, innovative and visionary social activists who 'borrow from an eclectic mix of business, charity and social movements to reconfigure solutions to community problems and deliver sustainable new social value'.

Social values and pro-environmental behaviours are often intertwined within the vision of the owners and the operation of the business, though one may dominate. Many of the 'ecopreneurial' theorists include social dimensions in their discussions, considering entrepreneurship as a vehicle for social and environmental change (Anderson and Anderson, 1998). Cohen et al. (2008) take a slightly different stance calling for an expanded view of the consequences of entrepreneurship to include economic, environmental, and social value. Hockerts (2006) suggests that at first glance ecopreneurship might be considered as one facet of social entrepreneurship, where the focus narrows to one aspect of the public 
good, that of environmental protection. Leadbeater $(2007$, p.5) presents a business continuum of social values that range from profit driven mainstream business (bringing social benefits as an unintended consequence) through to voluntary and non-markets solutions (where social benefits are the deliberate and intentional goal of the activity with profit playing no role). Within this continuum Leadbeater (2007) identifies two forms of business that intersect with the definitions of ecopreneurs detailed above. Socially responsible businesses lean towards the profit orientated perspective, with greater attention paid to supply chain management for ethical and environmental issues than mainstream businesses, and outputs demonstrate some elements of green (environmental) and social branding. Whereas, Social Enterprises are heavily biased towards social inclusion and environmental objectives, with some consideration of profit and consumer outputs with green, fair trade and social inclusion credentials central to brand identify.

In addition to considering the social / environmental focus a distinction can also be made between the integration of these values at the start-up stage (defined as green-green businesses (Isaak, 1997, 2002) or as a transformative process once an organisation is operating. Another dimension covered within the entrepreneurship literature is the characteristics of the entrepreneurial individual: the classic entrepreneur who sets up a small business that grows into a successful company (Schaper, 2005) or the corporate/intrapreneurs setting up new initiatives within existing organisations (Pinchot, 1985). Organisations themselves can also be considered to demonstrate entrepreneurial qualities in the way they innovate and develop new solutions (Schaper, 2005).

Walley and Taylor (2002, p.34) consider that green entrepreneurship should adopt as wide a definition as possible, including green start-ups, transforming businesses and those exploiting green niches with 'greenness' used as a catch-all term to describe a movement towards environmental or ecological sustainability, a triple bottom line perspective that considers economic prosperity, environmental quality and social/ethical considerations as three supporting pillars of sustainable development. This discussion therefore suggests a range of dimensions that influence the nature and extent of the integration of sustainability principles into an organisation. Within these businesses, the main agenda may be dominated by environmental concerns, social/equity concerns, be an offshoot of a lifestyle choice or be a mixture of these. These criteria are described in Table 1 presenting social or environmental dimensions against which businesses might be considered.

Table 1. Differences between traditional, social, and environmental enterprises

\begin{tabular}{|c|c|c|c|}
\hline Criteria & Categories & & \\
\hline $\begin{array}{l}\text { Stage of Business where social } \\
\text { and environmental issues } \\
\text { considered }\end{array}$ & $\begin{array}{l}\text { From start up as } \\
\text { eco/social business }\end{array}$ & $\begin{array}{l}\text { Transformation } \\
\text { of existing } \\
\text { business }\end{array}$ & \\
\hline $\begin{array}{l}\text { Key influences of integration of } \\
\text { sustainability concepts }\end{array}$ & Founder vision & $\begin{array}{l}\text { Internal green } \\
\text { champions }\end{array}$ & $\begin{array}{l}\text { External driver } \\
\text { such as regulation }\end{array}$ \\
\hline $\begin{array}{l}\text { Role of profit within business } \\
\text { mission }\end{array}$ & Profit maximisation & Profitable & Not for profit \\
\hline $\begin{array}{l}\text { Resource basis of product or } \\
\text { services }\end{array}$ & $\begin{array}{l}\text { Traditional goods } \\
\text { and services }\end{array}$ & $\begin{array}{l}\text { Environmental } \\
\text { resource or } \\
\text { service }\end{array}$ & Social service \\
\hline $\begin{array}{l}\text { Dominant paradigm of } \\
\text { business/organisation }\end{array}$ & Traditional & Environmental & Social \\
\hline
\end{tabular}


Within ecopreneurial businesses the economic dimension of sustainability is also crucial, as businesses need to operate as profit making enterprises or at least cover operating costs. However, drawing on the distinction made by Leadbeater (2007) vis-à-vis social enterprises some ecopreneurial businesses may not necessarily be driven by profit maximisation or constant growth (especially if not publicly held) and may only wish to earn a 'comfortable' income. Within this paper the common term of ecopreneurship also refers to studies that have previously used the terms enviropreneur, green or environmental entrepreneur.

Thus ecopreneurial businesses can be defined as profit generating businesses where environmental considerations are key to the business culture, product or service. They may include consideration of social values but as part of a synergistic balance with environmental concerns within a broader sustainability focus. They may start up with a environmentally based product or process, or have transformed to consider environmental issues as an integral component of their business culture. The focus of this definition is on the overall organisational culture rather than the ecopreneurial leanings of individuals, though this culture may be facilitated by, or a result of, green champions, founder ideals or key individuals (Drumwright, 1994; Ogbonna and Harris, 2001; Preston, 2001).

\section{Positioning Ecopreneurs}

A number of studies have sought to classify ecopreneurs (de Bruin and Lewis, 2005; Linnanen, 2005; Schaltegger, 2005; Walley and Taylor, 2002) typically using a matrix approach. Schaltegger (2005) uses the priority of environmental issues within the business (as core or supplementary goals) and the target market (from alternative, niche and mass market) to position ecopreneurship in relation to other forms of environmental management. De Bruin and Lewis (2005) also use market orientation in association with the level of response (ranging from personal concern, business opportunity or a collective social response). Linnanen (2005) also considers the motivations of environmental entrepreneurs using two criteria: the desire to make money and the desire to change the world, in order to position green ecopreneurs. In the Walley and Taylor (2002) study, the motivations and influences on individuals who are green entrepreneurs are used to develop a typology: innovative opportunists, visionary champions, ethical mavericks and ad hoc entrepreneurs.

Organisations can also be classified by the type of product or service that the organisation provides. Hendrickson and Tuttle (1997) provide a detailed classification of the environmental production focus of an enterprise. Environmental business types are presented by Eastwood et al. (2001) and Linnanen (2005) classifies ecopreneurs as comprising of at least the follow groups: nature orientated, producing environmental technology; providing environmental management services; and producing environmental friendly products.

\section{Business Lifecycle}

The Bennett sample consists of companies at various stages of their business lifecycle. Isaak (2002) provides the classification of green-green (green start-ups) or ecopreneurs (transformed existing organisations). However a more detailed business lifecycle approach is used within the broader entrepreneurial literature (after Churchill, 1983) detailed in Table 2. 
Table 2. Business lifecycle model of trading businesses (after Churchill, 1983)

\begin{tabular}{|l|l|}
\hline $\begin{array}{l}\text { Existence } \\
\text { stage }\end{array}$ & $\begin{array}{l}\text { The existence stage consists of the start-up stage focusing on developing a niche } \\
\text { market and customer base. Though this has no predetermined length, data from } \\
\text { the US Bureau of Labor Statistics found that one third of new establishments failed } \\
\text { in their first two years, with only 44\% still in existence in year 4 (Knaup, 2005). }\end{array}$ \\
\hline $\begin{array}{l}\text { Survival } \\
\text { stage }\end{array}$ & $\begin{array}{l}\text { Many of the 'mom-and-pop' businesses fall into this category, along with those of } \\
\text { marginal return and possible failure. }\end{array}$ \\
\hline $\begin{array}{l}\text { Success } \\
\text { stage }\end{array}$ & $\begin{array}{l}\text { Two success models, both include average or above average profits and economic } \\
\text { health: the success-growth stage where the business is growing and operates } \\
\text { under a fully engaged owner/ managers; and the success-disengagement stage, } \\
\text { where the business and owner managers may depart company with the owners } \\
\text { using the business as a means of support as they disengage. }\end{array}$ \\
\hline $\begin{array}{l}\text { Take-off } \\
\text { stage }\end{array}$ & $\begin{array}{l}\text { High growth, still dominated by the owner's presence and stock control. Some } \\
\text { elements of strategic and operational planning exist and this is often the point at } \\
\text { which the original founder sells or is forced out. }\end{array}$ \\
\hline $\begin{array}{l}\text { Resource } \\
\text { maturity }\end{array}$ & $\begin{array}{l}\text { A company in this stage engages in operational and strategic planning, with a } \\
\text { decentralised management structure. The owner and business are separate } \\
\text { financially and operationally. }\end{array}$ \\
\hline
\end{tabular}

Companies may have ceased trading, merged or been acquired and thus fall out of the business lifecycle model. Firms that provide niche services and products are often bought out or merge with others.

These niche products may continue as brands (e.g. Earth's Best), or they may continue as clearly defined subsidiaries within a holding company or group (e.g. Body Shop owned by L'Oréal), or disappear as their assets are used to expand the purchasing company (e.g. Bread and Circus stores converted to Whole Foods). Companies also fail, with high failure rates cited within start-ups and survival stage companies, examples include the $56 \%$ failing in first four years in the study by Knaup (2005). Companies are not immune to failure even in what might be considered mature stages, as recent high profile liquidations from 2008 onwards have shown (e.g. UK based Woolworths, Whittard's of Chelsea and Adams), as market conditions shift.

\section{Findings}

\section{The Original Sample}

The Bennett publication reflects the environmental conditions of the USA in the late 1980s and early 1990s. The post Brundtland policy and legislative climate of the late 1980 s promoted more environmentally responsible business practices and associated business creation opportunities. Many of the businesses associated with 'alternative' lifestyles were associated with products that had environmental dimensions (such as organic, chemical free, artist based, and ecotourism) but were also often intimately associated with strong social values. The sample is dominated by companies in the emerging waste management industries (driven by State legislation and mandatory recycling targets), the promotion of healthy alternative and greener products (such as natural, organic, vegetarian), new eco-efficiency technologies such as solar (helped by subsidies at State level), and pollution control industries. Businesses associated with recycled products forming $34 \%$ of the sample $(n=94)$, and those associated with eco-friendly products comprise $41 \%$. Those businesses associated with inputs dominate the sample (43\%), followed by $27 \%$ service and $17 \%$ outputs. Only $10 \%$ of business types were 
associated with the transformation stage of the production process. The majority of businesses associated with outputs are based on collection of post-consumer recycled wastes.

The start up dates for the original sample show that many of the Bennett ecopreneurs were in operation well before Brundtland in 1987. Three of the organisations were in operation in the 1920s and 30s (Atlantic Paper Company, Lundberg Farm and Milorganite Division). The Lundberg farm went organic in the 1960's, perhaps around the time of Rachel Carson's Silent Spring. The Milorganite Division produced fertilizer from sewage from the 1920s as a way to manage their waste disposal problems. However 42 of the 71 known start-up dates are in the 1980's and early 1990s. The fact that not all Bennett's ecopreneurs were 'born' environmentally responsible suggests that there is an element of green transformation occurring in response to the macro conditions of the time.

\section{Where are they now?}

One third of the sample have failed, with 27 companies not found online (no general web references, location or financial data) suggesting they have failed or closed down, and a further 4 are known failures through bankruptcy (Table 3). This seems to mirror the findings of Knaup (2005) who found one a one third failure rate, though lack of information on start up dates (and subsequent failure) for some of the Bennett sample prevents assessment of whether this was predominantly within two years of start up. Knuap (2005) also notes a $56 \%$ failure rate within the first four years and this suggests that survival rates across the Bennett sample of green business are higher.

Table 3. Bennett's Missing Ecopreneurs from 1991

\begin{tabular}{|l|l|}
\hline \multicolumn{2}{|c|}{ Vanished - no trace found online } \\
\hline $\begin{array}{l}\text { Alameda Aluminium Can } \\
\text { Recycling, Los Angeles (1982) }\end{array}$ & $\begin{array}{l}\text { Gas and aluminium recycling where depositors can redeem voucher } \\
\text { at gas station }\end{array}$ \\
\hline Anthony's Originals, Natick MA & $\begin{array}{l}\text { Kits for converting wrapping paper and other paper into decorative } \\
\text { envelopes (Envy-Lopes, Freeby-Bags) }\end{array}$ \\
\hline Blue Rhubarb, Harmony CA & Developed environmentally friendly product the 'EcoSac' \\
\hline California Glass Recycling Corp.; & West coast arm of Glass Packaging Institute \\
\hline $\begin{array}{l}\text { Cancelor Corporation, Arlington, } \\
\text { MA }\end{array}$ & Sorting systems for recycling \\
\hline $\begin{array}{l}\text { Earth Bags Ltd, Leesburg } \\
\text { Virginia }\end{array}$ & $\begin{array}{l}\text { Make environmentally friendly bags - in association with Industries } \\
\text { for the Blind industrial work sewing programme }\end{array}$ \\
\hline $\begin{array}{l}\text { Earthwise, Charlottesville } \\
\text { Virginia }\end{array}$ & \begin{tabular}{l} 
Green retail products store \\
\hline Ecobags, Ossining, NY (1989)
\end{tabular} \\
\hline $\begin{array}{l}\text { Ecological Agricultural Systems } \\
\text { Inc (1990) }\end{array}$ & $\begin{array}{l}\text { Biodegradable packaging (co-founder Steven Sommers of Alexander } \\
\text { Fruit \& Trading Co) }\end{array}$ \\
\hline
\end{tabular}




\begin{tabular}{|c|c|}
\hline $\begin{array}{l}\text { Ecological Systems Inc, } \\
\text { Bethesda Maryland }\end{array}$ & Water treatment using algae mat (Algal Turf Scrubber) \\
\hline $\begin{array}{l}\text { Ecology House (f), Portland } \\
\text { Oregon (1983) }\end{array}$ & $\begin{array}{l}\text { Retail store selling environmentally responsible goods - franchising } \\
\text { began in } 1988\end{array}$ \\
\hline $\begin{array}{l}\text { Ecotech Autoworks, McLean } \\
\text { Virginia }\end{array}$ & Collection point for used motor oil, recycled CFCs \\
\hline $\begin{array}{l}\text { Energy Recycling Group, } \\
\text { Brattleboro Vermont }\end{array}$ & Recovers landfill gas for electric generation \\
\hline $\begin{array}{l}\text { Express Lane, North Palm Beach } \\
\text { Florida }\end{array}$ & $\begin{array}{l}\text { Delivers environmentally friendly food, house wares and personal } \\
\text { care items alongside traditional goods. Collects used plastics bags for } \\
\text { recycling }\end{array}$ \\
\hline $\begin{array}{l}\text { Filtrona Co, Plymouth Michigan } \\
\text { (1988) }\end{array}$ & Filters for automobiles to remove environmental pollutants \\
\hline $\begin{array}{l}\text { Glass Aggregate Corporation, } \\
\text { Grand Rapids Michigan (1989) }\end{array}$ & $\begin{array}{l}\text { Converts crushed coloured glass too erosion barrier material and } \\
\text { drainage under roads - developed geo-textile bag to hold crushed } \\
\text { glass }\end{array}$ \\
\hline Home Diaper services (f); & $\begin{array}{l}\text { National Association of Diaper Services selling a kit to start own } \\
\text { business }\end{array}$ \\
\hline $\begin{array}{l}\text { Household Recycling Products } \\
\text { Andover MA; }\end{array}$ & Manufactures recycling bins from HDPE bottles \\
\hline Klark Hagan, Monticello lowa; & $\begin{array}{l}\text { Recycles local trash collected from residents (supplier for Hammers } \\
\text { Plastics Recycling Corp) }\end{array}$ \\
\hline $\begin{array}{l}\text { Necessity Trading Co. New } \\
\text { Castle Virginia (1970s); }\end{array}$ & $\begin{array}{l}\text { Organic farmer who produced own fertilizer - leased facilities to } \\
\text { expand local activities in } 1977\end{array}$ \\
\hline $\begin{array}{l}\text { Newhallville Recycling Inc New } \\
\text { Haven Connecticut }\end{array}$ & $\begin{array}{l}\text { sells or rents collection bins to clients for recycling paper, } \\
\text { newspapers, cardboard, bottles and cans }\end{array}$ \\
\hline Offshore Ventures (1988) & Organic fertilizer from fish products \\
\hline $\begin{array}{l}\text { Organic Carpet Care St Pauls } \\
\text { Minnesota }\end{array}$ & Environmentally sound carpet cleaning \\
\hline Safe Environments & Consulting firm (air pollution/sick buildings) \\
\hline Safer Products & Environmentally safe fertilizer and pest control products \\
\hline $\begin{array}{l}\text { Undaunted Recycler Eugene } \\
\text { Oregon (1990) }\end{array}$ & Used paper recycling \\
\hline $\begin{array}{l}\text { Worldview Financial Services } \\
\text { Birmingham Michigan }\end{array}$ & Green investment advisor \\
\hline & Declared bankrupt and assets sold \\
\hline
\end{tabular}




\begin{tabular}{|l|l|}
\hline $\begin{array}{l}\text { Ashdun Industries, Fort Lee New } \\
\text { Jersey (1988) }\end{array}$ & $\begin{array}{l}\text { Paper products using recycled paper (40 lines) expanded to cleaning } \\
\text { and laundry concentrates, light bulbs, baby wipes. } \\
\text { filed for chapter 11 bankruptcy date unknown }\end{array}$ \\
\hline $\begin{array}{l}\text { Matlack Environmental Service, } \\
\text { Durham North Carolina }\end{array}$ & $\begin{array}{l}\text { Recycling company. Appears to have gone bankrupt (chapter 7) in } \\
2001\end{array}$ \\
\hline & $\begin{array}{l}\text { Acquired company that produces insecticides for all natural } \\
\text { ingredients, selling composting tools and mail order gardening } \\
\text { suppliers. rebranded to Verdant, acquired number of companies, } \\
\text { listed. Delisted 1991 and assets broken up }\end{array}$ \\
\hline Ringer Corporation (Verdant) & $\begin{array}{l}\text { Multi-commodity recycling firm. Conglomerate of five units, in } 1989 \\
\text { went public. Filed for Chapter } 11 \text { bankruptcy in } 1990 \text { until } 1993 . \\
\text { Three of units sold by March } 1995\end{array}$ \\
\hline Tri-R systems & \\
\hline
\end{tabular}

However, as Table 4 indicates whilst 33\% of the original sample ceased trading by 2010 due to business failure, certain business types experienced greater failure rates that others within this sample, more akin to the figures suggested by Knaup (2005) for traditional SMEs. For instance in waste salvage operations $69 \%(11 / 16)$ of the businesses failed or disappeared. In the green services category $60 \%(3 / 5)$ are no longer operating and $37 \%$ of the 'green products' category have disappeared (10/27). In the 1990 s recycling was still an ad hoc activity with great uncertainty for businesses, with some proactive State level initiatives and subsidies. Many of these failed companies offered services associated with this 'vacuum' in this informal waste management industry or green products that failed to mainstream into viable long term businesses. Gurdon and Samson (2010) consider a sample of scientist-started ventures and found that $27 \%$ of the sample had failed after 12 years. Work by Dun and Bradstreet suggested $70 \%$ of small firms survived over 9 years (Selz, 1994). Whilst, Bates and Nucci (1985) suggest failure rates of $3 \%$ annually- which would equate to $56 \%$ over 20 years if we presume an average start date of 1990 . However the incomplete nature of the historical data makes comparison with statistics on mainstream business failures rates very problematic. Start-up dates, (if known at all), vary across the sample and information on failure dates is equally scant. Typically longitudinal data on start-ups takes a sample from a set year and of a set size and considers them over a defined period of time. The data in this paper relates to a sample of various ages and sizes that were operating in 1990/1 and as such are not directly comparable with these other longitudinal studies. In addition some of the Bennett examples have grown from micro firms into medium or large enterprises. The date at which this happened is also unknown, as is the actual size when they were included in the Bennett sample. The main conclusion that can be drawn from consideration of the failure rates is that certain sectoral groups within the Bennett sample fared better than other groups. 
Table 4: Bennett's ecopreneurs in 2010

\begin{tabular}{|c|c|c|c|}
\hline & Business Status in 2010 & & $\%$ \\
\hline \multirow{2}{*}{$\begin{array}{l}\text { Ceased } \\
\text { Trading }\end{array}$} & not found - appears to have failed/closed down & 27 & 28.7 \\
\hline & Failed - assets broken up & 4 & 4.3 \\
\hline \multirow[t]{4}{*}{ Acquired } & $\begin{array}{l}\text { Acquired (subsequent failure): Circo Glass Company (Allwaste) San } \\
\text { Francisco (1982); New England Container Recovery Inc (CRInc.) } \\
\text { (1982);Trimax Lumber Lincoln Park New Jersey; }\end{array}$ & 3 & 3.2 \\
\hline & $\begin{array}{l}\text { Acquired (sold for assets or renamed and not found): Bread and Circus } \\
\text { MA (1975); Nature Recordings Friday Harbor Washington (1986) }\end{array}$ & 2 & 2.1 \\
\hline & $\begin{array}{l}\text { Acquired (sold to become a branded product range in new company) } \\
\text { Earth's Best Burlington VT (1984); Nature's Gate Chatsworth CA; R W } \\
\text { Frookies Corporation Englewood, N.J (1998); Nasoya Leominster MA } \\
\text { (1977); Earthgro (Pride's Corner Farms), Lebanon Connecticut (1977) }\end{array}$ & 5 & 5.3 \\
\hline & Total no longer trading as a company or subsidiary & 41 & 44 \\
\hline \multirow[t]{3}{*}{$\begin{array}{l}\text { Still } \\
\text { Trading }\end{array}$} & $\begin{array}{l}\text { Now subsidiary (independent or partially independent): Body Shop; } \\
\text { Cyklop Downington Pennsylvania (1974); Tom's of Maine Kennebunk } \\
\text { (early 1970s); Real Goods Trading Company Ukiah CA (1978) }\end{array}$ & 4 & 4.3 \\
\hline & $\begin{array}{l}\text { Survival stage (no financial data or known micro company): Advantage } \\
\text { Laser Products Tuscaloosa Alabama; Advantage Radon Control Centers } \\
\text { (1990); AFM Enterprises Riverside CA (late 1970s); Alexander Valley Fruit } \\
\text { and Trading Company Geyserville CA (1983); Allen's Naturally Farmington } \\
\text { Michigan (1982); Autumn Harp Bristol Vermont (1977); Sinan Company } \\
\text { (1987); Brookfields Farm South Amherst MA; Center Street Grainery (was } \\
\text { Morning Glory) Bath Maine (1978); Clean Air Los Angeles; Dan Patenaude } \\
\text { Wisconsin (1988); E.L. Foust Co Ltd Elmhurst IL (1974); Ecco Bella Caldwell } \\
\text { NJ (1988); Ecological Engineering Associations Marion MA (1988); } \\
\text { Ecotour Expeditions Cambridge MA (1989); Environmental Testing and } \\
\text { Technology Inc San Diego CA (1987); Fred Davis Corporation Medfield MA } \\
\text { (1981); Hammers Plastics Recycling Corp lowa Falls lowa (1984); Hundt } \\
\text { Dairy Farm Coon Valley Wisconsin (1982); Livos PlantChemistry Santa Fe } \\
\text { New Mexico (1976); Montville Plastics \& Rubber Inc Parkman Ohio } \\
\text { (1984); Port-A-Pier Manitowoc Wisconsin (1969); Rainbow Blossom } \\
\text { Natural Food Store and Cafe Louisville Kentucky (1977); Solar Wave } \\
\text { Charlestown MA (1978); Sun Electric Co. Hamilton Montana (1985); The } \\
\text { Green Planet Newton MA (1990); Urban Ore Berkeley CA (1980); Vangel } \\
\text { Paper Company Baltimore Maryland (1988) }\end{array}$ & 28 & 29.8 \\
\hline & $\begin{array}{l}\text { Post survival stage (small or medium enterprise): ACVA Atlantic (1981); } \\
\text { Alternative Energy Engineering (Aee Solar) Redway CA; Atlantic Paper } \\
\text { Company Baltimore Maryland (1920); Aubrey Organics Florida (1967); } \\
\text { Gardens Alive Sunman Indiana (1988); Kinder, Lydenberg, Domini \& Co } \\
\text { (1988); Family Club House Inc (I Play) Ashville North Carolina (1982); } \\
\text { Lundberg Family Farm Sacramento CA (1937); MA Industries Peachtree } \\
\text { City Georgia (1969); Milorganite Division (1926); NaturaLawn Inc (f) } \\
\text { Maryland (1987); Plastic Pilings Inc Rancho Cucamonga CA (1985); } \\
\text { Progressive Securities Financial Services; Seventh Generation Colchester } \\
\text { Vermont (1989); Sobek Expeditions Angels Camp CA (1973); Solar Works }\end{array}$ & 16 & 17 \\
\hline
\end{tabular}


A further $11 \%$ are also no longer trading but due to acquisition by larger companies seeking to expand their product portfolios with niche 'green' products and services, acquiring brands (Frookies, Nasoya, Earth's Best, Nature's Gate), or seeking to expand geographically (Bread and Circus), or seeking to widen what services they offered in the value chain (the acquisition of waste management companies such as Allwaste). This pattern of acquisitions was noted in the Gurdon and Samson (2010) study of scientiststart ups where $18 \%$ (4/22) were acquired. Again comparison with mainstream micro enterprises is difficult and perhaps the value lies in comparing within the sample. Typically waste management companies were acquired in mergers, whereas companies with specialised food products were acquired to access this product range as a brand.

A consolidation effect is apparent within these highly specialised markets of waste management, green technology, and natural foods. Bread and Circus was one of a number of acquisitions by Whole Foods who are now the leading organic/natural foods supermarket chain. This consolidation effect is currently occurring within the solar industries as solar becomes a mainstream business activity. Real Goods Solar is a publicly traded, spin-off subsidiary of Gaiam Inc concentrating on expanding in the solar technologies market, and including the renowned Solar Living Center in Hopland, California. This part of the company is growing using an acquisitions strategy, and recently completed the purchase of Marin Solar (2007), Carlson Solar (2008), Independent Energy Systems (2009) and Regrid Power (2009). Coit (2008) cites the growth in the solar market, especially in California where the state began offering \$3 billion in subsidies, as the reason for the rapid expansion of companies like Real Goods. A pattern is emerging of these larger companies purchasing the smaller, privately owned mom-and-pop type solar companies, with a more limited resource base and less operational experience. This is a market space that is ripe for consolidation with no single company in California currently having more than $5 \%$ of the residential market (Anon, 2008) and this fragmentation perhaps parallels the fragmented industry structure apparent in the waste management and recycling industries in the early 1990s.

Other companies were also acquired for their niche products and successful operations (Body Shop was acquired by L'Oréal, Tom's of Maine by Colgate-Palmolive and Real Goods by Gaiam). However they all continue to operate, at least partially, as independent companies within a parent group, to capitalise on the well-developed brand identity. Another acquired brand was Earthgro fertilizer sold by Prides Corner Farm in 1998 to the larger company Scotts and this product remains one of their leading brands to this day. One of the original owners/founders (Prides Corner Farm) are still operating as a successful business growing in size themselves to over $\$ 20$ million in sales per year.

Interestingly a number of the companies appear to have had difficulties during their expansion (success and take off growth stages) phases. Some like the New England Container Recovery Inc and Cisco (Allwaste) were acquired by larger companies (Phillips and WMX), and then the purchasers filed for Chapter 7 bankruptcy within a couple of years. Trimax is another example of this, bought out by the larger US Plastic Lumber who acquired 14 companies in the mid 1990's but again ran into difficulties and assets sold off. All the companies who were sold and then failed were associated with the waste management industries. 
A number of companies have at some stage declared Chapter 11 bankruptcy, which allows for company reorganisation before coming out of bankruptcy (for example Safety-Kleen and Real Goods who recovered from this and are now successful operating). TRI R systems, after a rapid expansion and growth period became a listed company formed from five units. Of these only two now appear to be operating and the remnants of the company are back in a survival business stage. Verdant also grew rapidly and was publically listed, but delisted in 1991 and their assets broken up. Not all of the expanding companies went bankrupt; Appliance Recycling Centers of America demonstrates continued sustained growth with over $\$ 100$ million in sales per year.

It is also clear that a number of Bennett's ecopreneurs are the classic 'mom and pop' family firms who may never emerge from a survival stage. There are 28 (30\% of the sample) companies that are clearly in this stage. Future work should consider in more details the evolution of this much neglected segment of entrepreneurial studies. There is evidence of a number of successful businesses that still operate with the original founders in some capacity. Some, like Real Goods, are part of a parent company. Others such as Atlantic Paper and Vangel remain locally based, family firms but with a strong financial basis and steady growth.

Two of the cases studies have moved from ecoproducts. The organic farmer Dan Patenaude is now focused on cheese production but there is no mention of organic status on the website. Autumn Harp sought to move their eco-product range into mainstream markets but experienced financial problems in the late 1990s. Since their restructuring they have focused their business and now their website makes no mention of the ecoproduct range and they clearly state they are aiming at the mainstream cosmetics and personal care market. The Alexander Valley Fruit and Trading Company developed an eco-product (a natural packaging material eco-popcorn) as an adjunct to the main business of wine production. A similar example is found at the Hundt dairy farm that moved into making recycled bedding materials for cattle. The Hundts moved away from this towards selling the machinery that shreds the bedding - and they now sell the Rotochopper. Whereas, at Alexander Farm they still use the eco-popcorn but they appear not to sell this as a retail product, merely using it as the packaging material for their wine products.

There were four franchises in the original sample. Two of these, the Body Shop and NaturaLawn have been very successful, with data suggesting NaturaLawn has over 72 franchises across the US and the success of the BodyShop franchise worldwide is well-known. Two of the other franchises have been much less successful. The Diaper Home services business appears to have failed and is perhaps a victim of the controversy around whether there is more environmental impact from cleaning reusable diapers than using the disposable ones. The eco-products retail store franchise Ecology House appears to have two stores but neither has any details on the business and no mention of the parent franchise.

\section{Conclusions}

The early ecopreneurs of the 1990s, and indeed those predating this period, have developed goods and service that represented the emerging environmental markets of the time. Some of these have moved very clearly into the mainstream of business and are now popular consumer goods, especially those associated with food, waste and natural products. However these are very competitive markets and it is clear from examining where the Bennett ecopreneurs are now, that a number have failed to maintain a viable business since 1991. Others, much like a large fish swallowing a smaller one, have been bought out and merged in order to fuel expansion geographically and develop wider product portfolios. Tracking the evolution from small to medium to large firm and the permutations of overexpansion, 
takeover, growth, acquisitions, bankruptcy, and management changes over the evolution is an interesting topic and this paper provides some examples of companies where future researchers can explore these lifecycles.

Unlike much of the entrepreneurial literature that focuses on how to 'grow' businesses it is not just the traditional growth from small to large that this paper considers, but the small, niche, micro businesses that flourish in local communities. Critique is emerging of the growth paradigm that is so prevalent within the basic philosophy of environmental management (after Jackson, 2009). These kinds of ecopreneurial firms are essential within a 'beyond growth' economy and the social/community based enterprise models. Given the role that such firms play in terms of a diverse economy a major area of future research should consider these in more detail, using the preliminary exploration in this paper as a basis to explore what happens to the 'average Joe' green business. Some clues are evident: such as the natural food cafes and alternative technology businesses that still operate as micro-local enterprises.

Public policy initiatives appear crucial in the development of these emerging ecopreneurial businesses. Solar Works of Vermont was founded in 1980 by Leigh Seddon to sell, install and service solar electric generators, residential solar thermal systems, commercial hot water systems and engineering energy efficient buildings (Witten, 1990). The founder attributes the early boom years of the late 1970s and 1980 s to the income tax incentives offered by the Carter administration for renewable energy. Another example would be the $\$ 3$ billion in subsidies offered in California (Coit, 2008). Policy developments were also important in the waste management industries where state initiatives led to the development of small niche companies to service these.

This paper focuses on the ecopreneurial businesses and their evolution, not the motivations of their owners and founders. The Bennett publication tells some of the stories, but future research would need to trace these individuals and get from them their story of what has happened to their businesses over the last two decades and why they failed, were sold, or have not grown demonstrably in size. Further analysis of motivations and aspirations of these ecopreneurs would allow further consideration of the ecopreneurial typologies (de Bruin and Lewis 2005; Linnanen, 2005; Schaltegger, 2005; Walley and Taylor 2002,) and seek to replicate and validate these models. Interviews with the original founders would also allow the consideration of the role of management competencies and the venture capital. Randjelovic et al. (2003) suggested that venture capitalists have not noticed the potential of ecoorientated start-ups businesses, though arguably increasing policy initiatives in the carbon conscious business environment may be leading to more solar and renewable energy start ups.

There are other 'best practice' cases available online and 'in how to' books that are available to researchers, and this paper demonstrates that they can be used as historical records to examine the longitudinal evolution of small businesses and in this case ecopreneurship. Expanding the small sample presented by Bennett using the similar Berle (1991) publication may provide a larger sample for more detailed statistical analysis. This a major contribution of this research, illustrating the rich wealth of data, albeit with limitations, that is available in historical archival sources.

The sample size within the Bennett study precludes detailed statistical analysis but it is clear that some key themes emerge. These themes include:

- consolidation of specialised industries such as post-consumer waste management;

- mainstreaming of green product lines;

- acquisition of niche products and companies as a form of expansion for more mainstream firms;

- significant number of firms that remain in the survival growth phase; 
- the impact of policy initiatives such as renewable energy subsidies in promoting more eco-start-ups; and

- the opportunity that historical 'best practice' documents offer for tracking longitudinal evolution of companies.

The discussion of the facets of ecopreneurship and social enterprise presented in this paper, and the general green business literature, suggest that we are moving into a period of economic activity that considers the wider sustainability and triple bottom line principles of doing business. There is a clear need to explore how small businesses are operationalising the trade off between environmental, social and economic priorities. If sustainability principles are to infuse through all levels of society then we need new models of doing business. Legislation and societal drivers can be used to motivate stronger environmental, ethical and social performance in our largest companies. Yet lying mostly under the societal radar are vast numbers of small and micro-businesses. Within these are perhaps the innovators who will design the eco-technology of the future, or individuals like the founders of Gaiam, the Body Shop, Seventh Generation, Real Goods, and Tom's of Maine to name a few. These former small ecopreneurs now have a huge influence through their power as multinational enterprises, amongst their employees, customers and suppliers to promote their environmental and social values. It was not that long ago that operating a natural food store, running an organic farm, producing natural cosmetics, or installing solar technology was considered a business on the fringes of the market place. As business opportunities evolve in the sustainability arena it will be the rapidly moving, micro ecopreneurs that are most likely to seize the niche markets that emerge. Where they will be two decades from now is an interesting question and the patterns emerging in the Bennett study may offer some clues as to how these specialised industries will evolve.

\section{References}

Anderson, A.R., Anderson, A.R., 1998. Cultivating the Garden of Eden: environmental entrepreneuring. Journal of Organisational Change Management 11 (2): 135-144.

Anon. 2008. Real Goods Solar Inc at Canaccord Adams Annual Growth Conference. FD (Fair Disclosure) Wire, August 12, 2008 Tuesday

Barkemeyer, R., Figge, F., Hahn, T., Holt, D., 2009. Trends in sustainability, Journal of Corporate Citizenship, 33: 69-86.

Bates, T., Nucci, A. 1989. An analysis of small business size and rate of discontinuance. Journal of Small Business Management, 27 (4): 1-8

Bennett, S.J., 1991. Ecopreneuring the complete guide to small business opportunities from the environmental revolution. Wiley: New York.

Berle, G. 1991. The green entrepreneur: business opportunities that can save the earth and make you money. Liberty Hall Press: Blue Ridge Summit, PA.

BERR, 2008. Department for Business, Enterprise and Regulatory Reform Statistical Press Release URN 08/92 30th July 2008. Available: http://stats.berr.gov.uk/ed/sme/smestats2007-ukspr.pdf.

Churchill, N.C., 1983. The five stages of small business growth. Harvard Business Review 61(3): 30-49.

Cohen, B. 2006. Sustainable valley entrepreneurial ecosystems. Business Strategy and the Environment, 15 (1): 1-14.

Cohen, B., Smith, B., Mitchell, R., 2008. Toward a Sustainable Conceptualization of Dependent Variables in Entrepreneurship Research. Business Strategy and the Environment, 17 (2): 107-119.

Coit, M. 2008. Real Goods stock falls in Wall Street debut. The Press Democrat, May $8^{\text {th }}$ : http://www.pressdemocrat.com/article/20080508/NEWS/693746992 
de Bruin, A., Lewis, K. 2005. Green entrepreneurship in New Zealand: A micro-enterprise focus. In Schaper, M. (ed), Making Ecopreneurs: developing sustainable entrepreneurship. Ashgate, Burlington, VT, 61-70.

Dickson, B., Watkins, D., Foxall, J., 2007. The Working Partnership: SMEs and Biodiversity. Fauna \& Flora International: Cambridge, UK.

Drumwright, M.E., 1994. Socially responsible organisational buying: environmental concern as a noneconomic buying criterion. Journal of Marketing 58 (July): 1-19.

Dyllick, T. Hockerts, K. 2002. Beyond the business case for corporate sustainability. Business Strategy and the Environment, 11(2): 130-141.

Eastwood, D., Eaton, M., Guyer, C., Stark, T., 2001. An Examination of Employment Change in Northern Ireland's Environmental Industry, 1993-2003. European Environment, 11 (4): 197-210.

Elkington, J., 1997. Cannibals with forks the triple bottom line of 21st century business. Capstone: Oxford.

Freimann, J., Marxen, S., Schick, H., 2005. Sustainability in the start up process. In Making Ecopreneurs: developing sustainable entrepreneurship, Schaper, M., (ed). Ashgate: Burlington, VT; 108-121.

Gurdon, M.A., Samsom, K.J. 2010. A longitudinal study of success and failure amongst scientist-started ventures. Technovation, 30: 207-214

Hendrickson, L.U., Tuttle, D.B., 1997. Dynamic management of the environmental enterprise: a qualitative analysis. Journal of Organisational Change Management 10 (4): 363-382.

Hillary, R., (ed). 2000. Small and Medium-sized Enterprises and the Environment. Greenleaf Publishing Ltd: Sheffield.

Hockerts, K., 2006. Ecopreneurship: Unique research field or just 'more of the same. In Social Entrepreneurship, Mair, J., Robinson J, Hockerts K, (eds.). Palgrave Basingstoke: England; 209-214.

Holt, D., 2000. Supporting Environmental Improvements in Small and Medium-Sized Enterprises in the UK. Greener Management International 30: 29-49.

Isaak, R., 1997. Globalisation and green entrepreneurship. Greener Management International 18: 8090.

Isaak, R., 2002. The Making of the Ecopreneur. Greener Management International 38: 81-91.

Ivanko, J.D, 2008. ECOpreneuring putting purpose and the planet before profits. New Society Publishers: Gabriola Island, BC.

Jackson, T., 2009. Prosperity with Growth. Sustainable Development Commission: London.

Knaup, A.E., 2005. Survival and longevity in the Business Employment Dynamics data. Monthly Labor Review Bureau of Labor Statistics May: 50-56.

Larson, A. 2000. Sustainable innovation through and entrepreneurship lens. Business Strategy and the Environment, 9 (5): 304-317

Leadbeater, C., 2007. Social enterprise and social innovation: Strategies for the next ten years A social enterprise think piece for the Office of the Third Sector, November 2007. Cabinet Office Office of the Third Sector: London, UK.

Linnanen, L., 2005. An insider's experiences with environmental entrepreneurship. In Making Ecopreneurs: developing sustainable entrepreneurship, Schaper, M., (ed). Ashgate: Burlington, VT; 7288.

Lober, D.J., 1998. Pollution prevention as corporate entrepreneurship. Journal of Organisational Change Management, 11 (1): 26-37.

Masurel, E. 2007. Why SMEs invest in environmental measures: sustainability evidence from small and medium enterprises, Business Strategy and the Environment, 16 (3): 190-201.

Menon, A., Menon, A., 1997. Enviropreneurial marketing strategy: the emergence of corporate environmentalism as marketing strategy. Journal of Marketing 61 (January): 51-67. 
Nicholls, A., 2006. Social entrepreneurship new models of sustainable social change. Oxford University Press: Oxford.

O’Riordan, T., 1976. Environmentalism. Pion Limited: London.

Ogbonna, E., Harris, L.C., 2001. The founder's legacy: hangover of inheritance. British Journal of Management, 12 (1): 13-31.

Pinchot, G., 1985. Intrapreneuring : why you don't have to leave the corporation to become an entrepreneur. Harper and Row: New York.

Preston, L., 2001. Sustainability at Hewlett-Packard: from theory to practice. California Management Review, 43 (3): 26-37.

Randjelovic, J., O'Rourke, A.R., Orsato, R.J. 2003. The emergence of green venture capital. Business Strategy and the Environment, 12 (4): 240-253.

Revell, A., Blackburn, R., 2004. SMEs and Their Response to Environmental Issues in the UK. Small Business Research Centre: Kingston University, Surrey.

Saunders, T., 1993. The bottom line of green is black strategies for creating profitable and environmentally sound businesses. HarperSanFrancisco: San Francisco, California.

SBA, 2007. 2007. The Small Business Economy for Data Year 2006 - A Report to the President. U.S. Small Business Administration Office of Advocacy United States, Government Printing Office: Washington DC.

Schaltegger, S., 2005. A framework and typology of ecopreneurship: leading bioneers and environmental managers to ecopreneurship. In Making Ecopreneurs: developing sustainable entrepreneurship, Schaper, M., (ed). Ashgate: Burlington, VT; 43-60.

Schaper, M., 2002. The Essence of Ecopreneurship. Greener Management International 38: 26-30.

Selz, M. 1994. For business survival, bigger isn't necessarily better - smallest companies boast the lowest failure rates in d\&b survey. The Wall Street Journal, October 21: B2.

Walley, E.E., Taylor, D.W., 2002. Opportunists, Champions, Mavericks...? Greener Management International 38: 31-43.

WCED, 1987. Our Common Future: The World Commission on Environment and Development. Oxford University Press: Oxford

Witten, M. 1990. Environmental Sector Remains Healthy. Vermont Business Magazine 18 (12): 18. 